\title{
Accelerated aging test to evaluate the quality of crambe (Crambe abyssinica Hochst - Brassicaceae) seed physiology
}

\author{
Ensayo envejecimiento acelerado para evaluar la calidad fisiológica de las \\ semillas de crambe (Crambe abyssinica Hochst - Brassicaceae)
}

\author{
Elias Terra Werner ${ }^{1 *}$, José Carlos Lopes ${ }^{3}$, Diego Gomes Junior ${ }^{2}$, Jaquelini Luber ${ }^{3}$, \\ José Augusto Teixeira do Amaral
}

\begin{abstract}
SUMMARY
The present study aimed to evaluate the efficiency of the accelerated aging test to determination of the physiological potential of the Crambe abyssinica Hochst seeds, from two harvests (2009 and 2010). Were evaluated: water content, germination and vigor by germination speed index, accelerated aging in temperatures of 41,43 and $45{ }^{\circ} \mathrm{C}$ for $24,48,72$ and 96 hours, fresh and dry mass. The experiment was conducted in a $2 \times 3 \times 5$ factorial (batches $\mathrm{x}$ temperature $\mathrm{x}$ exposure time), in a completely randomized design, with four replicates of 25 seeds. The fresh and dry mass were not effective for distinguish the physiological quality of Crambe abyssinica seeds. The accelerated aging test influences, similarly, the percentage of germination and vigor, with greater sensitivity when the seeds treated with temperatures of 41 or $43{ }^{\circ} \mathrm{C}$, for $72 \mathrm{~h}$, and evidenced promising role to a stratification of the physiological quality of crambe seeds batches with similar germination.
\end{abstract}

Key words: Crambe abyssinica, biodiesel, germination, vigor.

\section{RESUMEN}

Este estudio tuvo como objetivo evaluar la eficacia de la prueba de envejecimiento acelerado, para determinar los efectos fisiológicos de semillas Crambe abyssinica Hochst, un montón de dos cosechas (2009 y 2010). Se evaluaron: contenido de agua, la germinación y el vigor por el índice de velocidad de la germinación, envejecimiento acelerado a 41,43 y $45^{\circ} \mathrm{C}$ durante períodos de 24, 48, 72 y 96 horas, el peso fresco y el peso seco. El experimento se llevó a cabo en el esquema factorial $2 \times 3 \times 5$ ( $m$ ucha $x$ temperatura x tiempo de exposición), en un diseño completamente al azar, con cuatro repeticiones de 25 semillas. El peso fresco y peso seco no son eficientes para diferenciar la calidad fisiológica de las semillas de Crambe abyssinica. Las influencias de envejecimiento acelerado, de manera similar, el porcentaje de germinación y el vigor, con una mayor sensibilidad cuando las semillas son tratadas con temperaturas de 41 o $43{ }^{\circ} \mathrm{C}$ durante $72 \mathrm{~h}$, lo que indica un papel prometedor para la estratificación de la calidad fisiológica de la semilla crambe de lotes con germinación similar.

Palabras clave: Crambe abyssinica, biodiesel, germinación, vigor.

\section{Introduction}

The crambe (Crambe abysinica) is a Brassicaceae originally from the Mediterranean Sea, extensively planted in Mexico and the United States. It was a species basically destined to the production of hay (30 to $32 \%$ of raw protein), and which is currently being widely grown for extraction of vegetable oil.
With the current incentives to the pursuit of renewable sources of energy, the culture of $C$. abyssinica has been gaining a distinct role in the production of biodiesel due to its various advantages, such as quick life cycle (harvest in about 90 days), high production of biomass, high yield of seeds (1000 and $1500 \mathrm{~kg} / \mathrm{ha}$ ), low production cost and a total percentage of oil in the seed between 26 and 38\%, overcoming, for example, the soybean in this last

\footnotetext{
1 Centro de Ciências Agrárias-Universidade Federal do Espírito Santo (CCA-UFES) - Campus de Alegre, Cx. Postal 16, CEP 29500-000, Alegre-ES, elias_werner@ig.com.br.

2 CCA-UFES - Campus de Jerônimo Monteiro.

3 CCA-UFES - Campus de Alegre.

* Autor para correspondência.
}

Fecha de Recepción: 14 Febrero, 2012.

Fecha de Aceptación: 11 Septiembre, 2012. 
characteristic (Paulose et al., 2010). In addition to being used in the production of biodiesel, it can be feasible in phytoremediation, effective in the decontamination of arsenic, chrome and other heavy metals (Artus, 2006), also useful in the plastic and lubricant industries due to the high percentage of erucic acid (50 to a 60\%) (Pitol, 2008). Jasper et al. (2010) have shown that the culture of crambe presents lower production cost than other oleaginous sources, such as canola, sunflower and soybean.

Only a few studies have been performed with the crambe, considering its employment in the agricultural energy, opening a wide field for investigations that have the purpose of getting to know and developing the potentiality of this culture, in order to improve the agronomic and technologic aspects for its use in the biodiesel industry.

Researchers and seed analysts are concerned about conducting studies that provide information about the quality of the seeds, especially regarding standardization, speeding up and establishment of more effective analysis methods. A few papers were developed with Crambe abyssinica seeds (Masetto et al., 2009; Martins et al., 2011); however none characterized a vigor trial for effective assessment of the physiologic potential of the species' seeds.

The assessment of the physiologic potential of the seeds constitutes a fundamental component in the quality control programs of producers or in order to characterize the seeds destined to commercialization. Amongst the trials used for such assessment, the accelerated, precocious or artificial aging is distinct, which has the basic purpose to identify potential differences in the resistance of batches that present a similar germinative power (Torres and Marcos Filho, 2001). According to these authors, the trial may be considered as one of the most sensitive for the assessment of vigor amongst the currently available trials.

The accelerated aging test is based on the fact that the seeds' deterioration rate is considerably increased by their exposure to really adverse levels of temperature and relative humidity, considered as the environmental factors that are more related to deterioration (Marcos Filho, 1999), thus, assessing both with the relative potential of storage of seed batches and the emergence of seedlings in agricultural production fields.

Although this trial is being widely studied aiming at its standardization for lots of species, information is scarce for crambe seeds if compared to the seeds of large cultures. In light of the foregoing, the purpose of the present paper was to assess the effectiveness of the accelerated aging test, in order to determine the physiologic potential of Crambe abyssinica Hochst seeds, from two crops (2009 and 2010).

\section{Material and Methods}

The work was conducted at the Laboratory of Seed Analysis of the Center of Agricultural Sciences in the Federal University of Espírito Santo (Laboratório de Análise de Sementes do Centro de Ciências Agrárias da Universidade Federal do Espírito Santo), located in Alegre-ES, using Crambe abyssinica Hochst seeds from the 2009 (batch 1) and 2010 (batch 2) crops, obtained with the MS Foundation, located in Maracujá-MS. The seeds were stored in permeable paper bags in a refrigerator. The following assessments and/or determinations were made for both batches in the period from May to June 2011:

\section{Water Contents}

Performed initially and subsequently at each temperature/accelerated aging period, through the kiln method at $105 \pm 3{ }^{\circ} \mathrm{C}$, for 24 hours, using two samples of 30 seeds for each batch. Results were expressed in percentage.

\section{Germination}

Conducted with four replications with 25 seeds/ period/temperature for each tested batch, distributed in Petri dishes covered with two germitest paper sheets, damp with a distilled water amount equivalent to 2.5 times the weight of the dry paper sheets, subsequently maintained in germination chambers type BOD with regulated temperature of $25 \pm 2{ }^{\circ} \mathrm{C}$, equipped with cold and white fluorescent lamps, with photoperiod of 8-16 h (light-dark). Assessments were performed daily and, at the end, the germination result was expressed in average percentage of regular seedlings for each temperature/exposure time.

\section{Germination Speed Index (GSI)}

Conducted concomitantly with the germination test, with daily calculation of the number of seeds that presented protrusion of primary root with length 
$\geq 2 \mathrm{~mm}$, always at the same time during the trial. The germination speed index was calculated by the sum of the number of seeds germinated each day, divided by the number of days elapsed between the seeding and germination, according to the Maguire formula (1962):

$$
G S I=\frac{G 1}{n 1}+\frac{G 2}{n 2}+\ldots+\frac{G i}{n i}, \text { where: }
$$

GSI = seedlings' germination speed index;

$\mathrm{G}=$ number of seeds germinated each day;

$\mathrm{N}=$ number of days elapsed from the seeding until the last count.

\section{Accelerated Aging Test}

This trial was conducted by the gerbox method, adjusted to form a humid chamber (100\% humidity), adapting the methodology proposed by Marcos Filho (1999). Gerbox plastic boxes with 11 x 11 x $3 \mathrm{~cm}$ were used adapted as mini chambers, with $40 \mathrm{~mL}$ of distilled water added to their interior, and 130 seeds were evenly placed per treatment in a wire mesh suspended, after being sealed. The boxes were subsequently maintained in BOD's regulated in temperatures of 41,43 and $45^{\circ} \mathrm{C}$ for periods of 24, 48, 72 and 96 hours. After these periods, seeds were submitted to the germination test, as previously described. The experiment was assessed by the germination percentage and germination speed index (GSI) (Maguire, 1962).

\section{Fresh and Dry Mass}

The fresh mass was quantified through weighing in precision scale, and the dry mass was determined through weighing in a precision scale after permanence of the material in a kiln with air forced circulation, at a temperature of $70^{\circ} \mathrm{C}$, until constant weight.

\section{Experimental Design and Statistical Analysis}

The experiment was conducted under a $2 \times 3 \times 5$ factorial scheme (seed batch $\mathrm{x}$ temperature $\mathrm{x}$ exposure time), in a completely randomized design (CRD), with four replications with 25 seeds per treatment. Data in percentage were transformed in arcsine $\sqrt{x / 100}$ and the germination speed index data in $\sqrt{x+0.5}$, however in the tables the original data are shown. The results were submitted to variance analysis and the averages compared by Tukey test $(\mathrm{p} \leq 0.05)$. Polynomial regression analysis was performed for germination and GSI, in function of the temperature and exposure time, and models were chosen based on the significance of the regression coefficient and determination coefficient (R2), adopting the levels of 1 and $5 \%$ of probability, using the F test, considering the biological phenomenon under study. For the execution of statistical analyses, the software Assistat and Sigma Plot 10.0 were used.

\section{Results and Discussion}

The results of water contents of crambe seeds, before (initial-T0) and after the various periods of accelerated aging at 41,43 and $45^{\circ} \mathrm{C}$, are showed in Table 1. The water contents, previous to the seed aging period, for batches 1 and 2 were $9.06 \%$ and $7.17 \%$, respectively. A similar result was described by Masetto et al. (2009), in which the average amounts regarding the water contents of crambe seeds after benefaction were found as between $6.5 \%$ and 9.4\%. Delouche and Potts (1974) highlight that after the harvest the humidity of oleaginous seeds must be reduced to $11 \%$ or less, due to the fact that seeds with high humidity contents quickly lose the viability and vigor. The initial water contents observed in this study suggest that this parameter was found in the indicated range for the performance of the accelerated aging test. Differences of 1 to $2 \%$ in the water contents between samples are not compromising (Marcos Filho, 1999).

There has been no significant interaction between the two factors tested for each batch (temperature and aging time). Regarding the aging time, comparing the two batches, it is observed little difference between the water contents, and the biggest difference was observed in the initial period (T0) (Table 1). The water contents of both seeds batches, in general, increased gradually during the initial aging phase, subsequently decreasing in the three temperatures tested. Seeds from batch 1 (2009) showed a higher water contents until 72 hours, with average value of $30.12 \%$, while seeds from batch 2 (2010), until $48 \mathrm{~h}$, with average of $32.03 \%$, both progressively reducing after those periods. Such behavior was observed by the averages of the aging periods (Table 1). Santos and Paula (2007) observed a similar behavior in the water contents of different batches of Sebastiania 
Table 1. Water content (\%) of Crambe abyssinica seeds, batches 1 (2009) and 2 (2010), before (initial - T0) and after accelerated aging test of 41,43 and $45^{\circ} \mathrm{C}$ for $24,48,72$ and 96 hours.

\begin{tabular}{lcccccc}
\hline \multirow{2}{*}{ Temperatures $\left({ }^{\circ} \mathrm{C}\right)$} & \multicolumn{5}{c}{ Batch 1 (2009) } & Mean \\
\cline { 2 - 6 } & Initial (T0) & 24 & 48 & 72 & 96 & $25.48 \mathrm{a}$ \\
\hline 41 & 9.06 & 25.14 & 31.41 & 32.16 & 29.63 & $21.66 \mathrm{~b}$ \\
43 & 9.06 & 20.77 & 27.26 & 25.48 & 25.70 & $25.68 \mathrm{a}$ \\
45 & 9.06 & 26.88 & 30.10 & 32.73 & 29.65 & \\
Mean & $9.06 \mathrm{C}$ & $24.26 \mathrm{~B}$ & $29.59 \mathrm{~A}$ & $30.12 \mathrm{~A}$ & $28.33 \mathrm{AB}$ & \\
\hline \multicolumn{5}{c}{$\mathrm{CV}(\%)=9.61$} \\
\end{tabular}

\begin{tabular}{lcccccc}
\hline \multirow{2}{*}{ Temperatures $\left({ }^{\circ} \mathrm{C}\right)$} & \multicolumn{5}{c}{ Batch 2 $(2010)$} & Mean \\
\cline { 2 - 6 } & Initial (T0) & 24 & 48 & 72 & 96 & $25.92 \mathrm{a}$ \\
41 & 7.17 & 26.07 & 33.28 & 30.87 & 32.20 & $21.98 \mathrm{~b}$ \\
43 & 7.17 & 21.88 & 27.76 & 27.06 & 26.04 & $26.94 \mathrm{a}$ \\
45 & 7.17 & 28.91 & 35.06 & 33.38 & 30.20 & \\
Mean & $7.17 \mathrm{C}$ & $25.62 \mathrm{~B}$ & $32.03 \mathrm{~A}$ & $30.44 \mathrm{AB}$ & $29.48 \mathrm{AB}$ & \\
\hline
\end{tabular}

$\mathrm{CV}(\%)=12.89$

Means followed by different letters, lowercase in the column and uppercase in the line, are significantly different by Tukey test (5\% probability). CV (\%): coefficient of variation.

commersoniana (Branquilho-Euphorbiaceae) seeds submitted to the accelerated aging test. Such behavior may be related to the initial water contents of the seeds, in which seeds from batch 1 , due to presenting a higher water contents, were soaked more slowly, and the seeds from batch 2, with lower water contents, were soaked more quickly. Freitas and Nascimento (2006) observed in lentil seeds, aged through the traditional method, increased humidity level as the aging periods increased, evidencing, similarly, that drier seeds, due to presenting low matric potential, absorb water quickly when placed in a humid atmosphere (Bewley and Black, 1994).

A few authors have commented that there is a relationship between the initial water contents of the seeds and the physiologic quality, and that seeds with lower initial water contents present a better physiologic quality (Rossetto et al., 1997).

The pace of water absorption by seeds, during aging, depends on the batch and the temperature in the aging chamber (Santos and Paula, 2007). Regarding temperature, the water contents of the seeds from both batches were similar (Table 1), and the highest absolute values were found in batch 2 . For batches 1 and 2, it is observed that the values obtained are higher at 41 (25.48 and 25.92\%, respectively) and $45^{\circ} \mathrm{C}$ (25.68 and $26.94 \%$, respectively) and that lower values are found at $43{ }^{\circ} \mathrm{C}(21.66$ and
$21.98 \%$, respectively). This suggests that the seeds submitted to 41 and $45{ }^{\circ} \mathrm{C}$ profit better from the water absorbed in the reserves metabolism, and, at $43{ }^{\circ} \mathrm{C}$, there has been a slower absorption of water, in lower proportion.

The lower water contents observed in seeds treated at a temperature of $43{ }^{\circ} \mathrm{C}$ may be attributed to higher damages to the seeds in this temperature than at temperatures of 41 and $45^{\circ} \mathrm{C}$. Such damages may manifest in different levels, such as degenerative changes in the seeds' metabolism, resulting from, for example, denaturation of proteins, decrease in total carbohydrate, soluble carbohydrates and proteins contents, increased reductive sugar and free fatty acids contents, unbalancing of enzyme activity and RNA and proteins syntheses (Vázquez et al., 1991). These alterations, in general, may be triggered by loss of structure and integrity of the cellular membrane systems, caused mainly by peroxidation of lipids (Marcos Filho, 1999). Therefore, the water contents assessment in seeds from different batches of crambe under accelerated aging test was not a proper parameter to distinguish regarding physiologic quality.

Toledo and Marcos Filho (1977) verified a decreased germination percentage as the humidity contents of the seeds were increased. The differences in the initial quality of tested batches of crambe 
seeds may be observed by the germination results (Table 2 and Figure 1A and 1B) and by the vigor, assessed by the germination speed index (GSI) (Table 3 and Figure 1C and 1D). It was verified the expected in both assessment, in which batch 1 (2009) showed lower physiologic quality than batch 2 (2010), however with a similar behavior in the accelerated aging test. On Tables 2 and 3 are represented, respectively, germination data and germination speed index (GSI) of seeds from batch 1 and 2, referring to the treatment with accelerated aging (different temperatures and exposure hours).

The lowest germination and germination speed index (GSI) values of batch 1 evidence the lower quality of those seeds, probably due to their harvest time, associated to their higher humidity level, which, allied to high temperatures $\left(41,43\right.$ and $\left.45^{\circ} \mathrm{C}\right)$, resulted in a more accelerated deterioration process. According to Carvalho and Nakagawa (2000), increased humidity levels favor the increase of the seed temperature, due to respiratory processes and increased activity of microorganisms, thus impairing its viability.

Nevertheless, it is observed, for batch 2, that both for germination percentage and germination speed index (GSI), in temperatures of 41 and $43{ }^{\circ} \mathrm{C}$ there has not been a significant reduction of those values within the exposure times from zero to $48 \mathrm{~h}$, whereas, as of 72 hours of exposure to accelerated aging, germination and GSI were reduced gradually. As for the $45{ }^{\circ} \mathrm{C}$ temperature, the values obtained reduced significantly as of $48 \mathrm{~h}$, reaching $0 \%$ after $96 \mathrm{~h}$ of exposure. Similar results were reported by Maia et al. (2007) in artificially aged wheat seeds, at the same temperatures and time employed in the present study.

Germination percentage and GSI values in temperatures of 41 and $43{ }^{\circ} \mathrm{C}$, were also significantly different amongst themselves in the $96 \mathrm{~h}$ period of aging exposure, and the highest value was found at $43{ }^{\circ} \mathrm{C}$ temperature in the $24 \mathrm{~h}$ exposure time. However, comparing the average values, the $41^{\circ} \mathrm{C}$ temperature was higher and statistically different from the other temperatures tested. In all aging periods assessed, the temperature of $45{ }^{\circ} \mathrm{C}$ was statistically lower than the other ones tested.

The behavior of germination and vigor assessed by the germination speed index (GSI) of seeds from both batches of crambe, in function of the periods of exposure to accelerated aging, is illustrated in Figure 1. The regression analysis of data enabled the adjustment of linear equation for all temperatures, both for batch 1 and batch 2. Observing Figure 1, it is evidenced that the temperature of $43^{\circ} \mathrm{C}$, initially, stimulated the germination and GSI of seeds, for both batches, and for batch 1 those parameters showed reduction after $72 \mathrm{~h}$, and, for batch 2 , after $24 \mathrm{~h}$. In all graphs presented, it is observed a progressive

Table 2. Germination (\%) of Crambe abyssinica seeds, batches 1 (2009) and 2 (2010), before (initial - T0) and after accelerated aging test of 41,43 and $45^{\circ} \mathrm{C}$ for $24,48,72$ and 96 hours.

\begin{tabular}{lcccccc}
\hline \multirow{2}{*}{ Temperature $\left({ }^{\circ} \mathrm{C}\right)$} & \multicolumn{3}{c}{ Batch $1(2009)$} & Mean \\
\cline { 2 - 5 } & Initial (T0) & 24 & 48 & 72 & 96 & $15.80 \mathrm{a}$ \\
\hline 41 & $27 \mathrm{aA}$ & $19 \mathrm{abAB}$ & $14 \mathrm{aAB}$ & $10 \mathrm{aAB}$ & $9 \mathrm{aB}$ & $18.00 \mathrm{a}$ \\
43 & $27 \mathrm{aA}$ & $28 \mathrm{aA}$ & $25 \mathrm{aA}$ & $10 \mathrm{aA}$ & $0 \mathrm{bB}$ & $10.00 \mathrm{~b}$ \\
45 & $27 \mathrm{aA}$ & $9 \mathrm{bB}$ & $14 \mathrm{aAB}$ & $0 \mathrm{bC}$ & $0 \mathrm{bC}$ & $3.00 \mathrm{~B}$ \\
Mean & $27.00 \mathrm{~A}$ & $18.66 \mathrm{~A}$ & $17.66 \mathrm{~A}$ & $6.66 \mathrm{~B}$ & \\
\hline
\end{tabular}

$\mathrm{CV}(\%)=37.83$

\begin{tabular}{lcccccc}
\hline \multirow{2}{*}{ Temperature $\left({ }^{\circ} \mathrm{C}\right)$} & \multicolumn{5}{c}{ Batch 2 $(2010)$} & Mean \\
\cline { 2 - 5 } & Initial (T0) & 24 & 48 & 72 & 96 & $73.60 \mathrm{a}$ \\
\hline 41 & $92 \mathrm{aA}$ & $95 \mathrm{aA}$ & $81 \mathrm{abA}$ & $60 \mathrm{aB}$ & $40 \mathrm{aB}$ & $66.80 \mathrm{~b}$ \\
43 & $92 \mathrm{aA}$ & $97 \mathrm{aA}$ & $88 \mathrm{aA}$ & $52 \mathrm{aB}$ & $5 \mathrm{bC}$ & $50.40 \mathrm{c}$ \\
45 & $92 \mathrm{aA}$ & $81 \mathrm{bAB}$ & $69 \mathrm{bB}$ & $10 \mathrm{bC}$ & $0 \mathrm{bD}$ & $15.00 \mathrm{D}$ \\
Mean & $92.00 \mathrm{~A}$ & $91.00 \mathrm{~A}$ & $79.33 \mathrm{~B}$ & $40.66 \mathrm{C}$ & \\
\hline \multicolumn{7}{c}{$\mathrm{CV}(\%)=13.00$} \\
\hline
\end{tabular}

Means followed by different letters, lowercase in the column and uppercase in the line, are significantly different by Tukey test (5\% probability). CV (\%): coefficient of variation. 


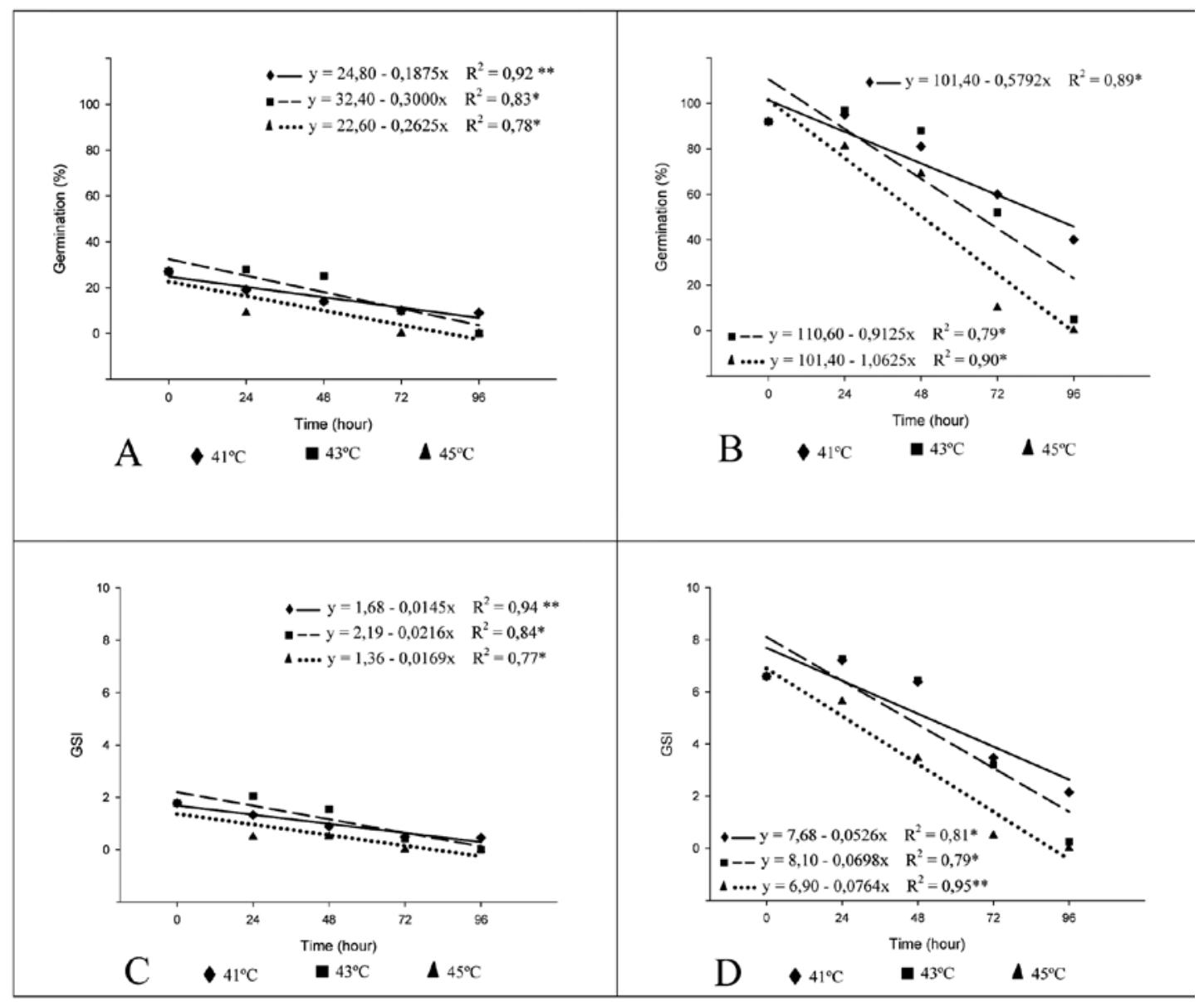

Figure 1. Polynomial regression of mean values of germination and GSI of Crambe abyssinica seeds submitted to accelerated aging. A - germination percentage of batch 1 (2009), B - germination percentage of batch 2 (2010), C - GSI of batch 1 (2009) and $\mathrm{D}$ - GSI of batch 2 (2010). (* $-\mathrm{P} \leq 5 \%$; ** $-\mathrm{P} \leq 1 \%)$.

reduction in the germination percentage and in germination speed index (GSI) for temperatures tested in relation to the exposure time.

Batch 1, characterized as initial lower quality, due to the low germination amount (27\%), showed a trend of reduced germination percentage and GSI after 24 hours. Batch 2, with increased exposure period to accelerated aging, showed reduced germinative power of seeds after 24 hours, at both temperatures.

Therefore, the accelerated aging test was found to be similarly influential in the germination percentage and the vigor of seeds, suggesting a higher sensitivity when exposed during 72 h to 41 or 43 ${ }^{\circ} \mathrm{C}$, being a promising manner for stratification of the physiologic quality of crambe seeds from batches with similar germination. A similar result was obtained for mustard seeds, for which the exposure to aging for 96 hours showed decreased germination and seedling vigor, enabling the distinction between batches (Bedi et al., 2006).

Analyzing the fresh mass (Table 4) and the dry mass (Table 5) of seedlings arising from the seeds submitted to different temperatures for different exposure times, it is observed, for both tested batches, a significant effect between those two factors. For seeds originated both from batch 1 and batch 2, fresh mass and dry mass showed similar behavior. It was verified that for batch 1 , such variables presented a decrease with increased temperature and aging exposure time; however, statistically differentiated only in temperature of $45{ }^{\circ} \mathrm{C}$ and time of $72 \mathrm{~h}$, and, for batch 2 , those differences were observed at the same temperature, but only after $96 \mathrm{~h}$ of aging exposure. 
Table 3. Germination speed index (GSI) of Crambe abyssinica seeds, batches 1 (2009) and 2 (2010), before (initial - T0) and after accelerated aging test of 41,43 and $45^{\circ} \mathrm{C}$ for $24,48,72$ and 96 hours.

\begin{tabular}{|c|c|c|c|c|c|c|}
\hline \multirow{2}{*}{ Temperature $\left({ }^{\circ} \mathrm{C}\right)$} & \multicolumn{5}{|c|}{ Batch 1 (2009) } & \multirow{2}{*}{ Mean } \\
\hline & Initial (T0) & 24 & 48 & 72 & 96 & \\
\hline 41 & 1.78 & 1.32 & 0.88 & 0.49 & 0.45 & $0.98 \mathrm{a}$ \\
\hline 43 & 1.78 & 2.04 & 1.53 & 0.42 & 0.00 & $1.15 \mathrm{a}$ \\
\hline 45 & 1.78 & 0.48 & 0.51 & 0.00 & 0.00 & $0.55 \mathrm{~b}$ \\
\hline Mean & $1.78 \mathrm{~A}$ & $1.28 \mathrm{AB}$ & $0.97 \mathrm{~B}$ & $0.30 \mathrm{C}$ & $0.15 \mathrm{C}$ & \\
\hline \multicolumn{7}{|c|}{$\mathrm{CV}(\%)=18.48$} \\
\hline \multirow{2}{*}{ Temperature $\left({ }^{\circ} \mathrm{C}\right)$} & \multicolumn{5}{|c|}{ Batch 2 (2010) } & \multirow{2}{*}{ Mean } \\
\hline & Initial (T0) & 24 & 48 & 72 & 96 & \\
\hline 41 & $6.59 \mathrm{aA}$ & $7.21 \mathrm{aA}$ & $6.38 \mathrm{aA}$ & $3.47 \mathrm{aB}$ & $2.15 \mathrm{aB}$ & $5.16 \mathrm{a}$ \\
\hline 43 & $6.59 \mathrm{aA}$ & $7.27 \mathrm{aA}$ & $6.43 \mathrm{aA}$ & $3.20 \mathrm{aB}$ & $0.25 \mathrm{bC}$ & $4.75 \mathrm{~b}$ \\
\hline 45 & $6.59 \mathrm{aA}$ & $5.63 \mathrm{bA}$ & $3.45 \mathrm{bB}$ & $0.49 \mathrm{bC}$ & $0.00 \mathrm{bC}$ & $3.23 \mathrm{c}$ \\
\hline Mean & $6.59 \mathrm{~A}$ & $6.70 \mathrm{~A}$ & $5.42 \mathrm{~B}$ & $2.38 \mathrm{C}$ & $0.80 \mathrm{D}$ & \\
\hline \multicolumn{7}{|c|}{$\mathrm{CV}(\%)=8.88$} \\
\hline
\end{tabular}

Means followed by different letters, lowercase in the column and uppercase in the line, are significantly different by Tukey test (5\% probability). CV (\%): coefficient of variation.

Table 4. Fresh mass (mg) of Crambe abyssinica seedlings, batches 1 (2009) and 2 (2010), before (initial - T0) and after accelerated aging test of 41,43 and $45^{\circ} \mathrm{C}$ for $24,48,72$ and 96 hours.

\begin{tabular}{|c|c|c|c|c|c|c|}
\hline \multirow{2}{*}{ Temperature $\left({ }^{\circ} \mathrm{C}\right)$} & \multicolumn{5}{|c|}{ Batch 1 (2009) } & \multirow{2}{*}{ Mean } \\
\hline & Initial (T0) & 24 & 48 & 72 & 96 & \\
\hline 41 & $91.7 \mathrm{aA}$ & $98.0 \mathrm{aA}$ & $94.4 \mathrm{abA}$ & $80.8 \mathrm{aA}$ & $0.0 \mathrm{aB}$ & $72.98 \mathrm{a}$ \\
\hline 43 & $91.7 \mathrm{aA}$ & $91.7 \mathrm{abA}$ & $101.4 \mathrm{aA}$ & $15.6 \mathrm{bB}$ & $0.0 \mathrm{aB}$ & $60.08 \mathrm{a}$ \\
\hline 45 & $91.7 \mathrm{aA}$ & $58.3 \mathrm{bA}$ & $57.9 \mathrm{bA}$ & $0.0 \mathrm{bB}$ & $0.0 \mathrm{aB}$ & $41.56 \mathrm{~b}$ \\
\hline Mean & $91.70 \mathrm{~A}$ & $82.63 \mathrm{~A}$ & $84.58 \mathrm{~A}$ & $32.15 \mathrm{~B}$ & $0.0 \mathrm{C}$ & \\
\hline
\end{tabular}

$\mathrm{CV}(\%)=1.97$

\begin{tabular}{lcccccc}
\hline \multirow{2}{*}{ Temperature $\left({ }^{\circ} \mathrm{C}\right)$} & \multicolumn{5}{c}{ Batch 2 $(2010)$} & Mean \\
\cline { 2 - 6 } & Initial (T0) & 24 & 48 & 72 & 96 & $63.3 \mathrm{a}$ \\
\hline 41 & $60.5 \mathrm{aA}$ & $63.3 \mathrm{aA}$ & $59.4 \mathrm{aA}$ & $63.4 \mathrm{abA}$ & $70.0 \mathrm{aA}$ & $56.1 \mathrm{a}$ \\
43 & $60.5 \mathrm{aAB}$ & $50.7 \mathrm{aAB}$ & $61.8 \mathrm{aAB}$ & $72.0 \mathrm{aA}$ & $35.8 \mathrm{bB}$ & $42.6 \mathrm{~b}$ \\
45 & $60.5 \mathrm{aA}$ & $50.7 \mathrm{aA}$ & $60.4 \mathrm{aA}$ & $41.5 \mathrm{bA}$ & $0.0 \mathrm{cB}$ & \\
Mean & $60.5 \mathrm{~A}$ & $54.8 \mathrm{~A}$ & $60.5 \mathrm{~A}$ & $58.9 \mathrm{~A}$ & $35.2 \mathrm{~B}$ & \\
\hline
\end{tabular}

$\mathrm{CV}(\%)=1.36$

Means followed by different letters, lowercase in the column and uppercase in the line, are significantly different by Tukey test (5\% probability). CV (\%): coefficient of variation.

According to Amaral et al. (1995), this reduction observed in the fresh mass and, consequently, the dry mass of crambe seedlings may be due to gradual desiccation of seeds, loss of structural material (membranes and cellular wall) and reserves under the temperatures tested. In general, throughout the experiment, the fresh mass amounts, as well as the dry mass amounts of the seedlings, were similar during the exposure times. Similar results were described by other authors (Lopes et al., 2008; Santos and Paula, 2009). Thus, it may be considered that this trial showed low sensitivity for differentiation of batches, since similar amounts of fresh mass or dry mass are observed in batches with different germination. 
Table 5. Dry mass (mg) of Crambe abyssinica seedlings, batches 1 (2009) and 2 (2010), before (initial - T0) and after accelerated aging test of 41,43 and $45^{\circ} \mathrm{C}$ for $24,48,72$ and 96 hours.

\begin{tabular}{lcccccc}
\hline \multirow{2}{*}{ Temperature $\left({ }^{\circ} \mathrm{C}\right)$} & \multicolumn{5}{c}{ Batch $1(2009)$} & Mean \\
\cline { 2 - 6 } & Initial (T0) & 24 & 48 & 72 & 96 & $4.46 \mathrm{a}$ \\
41 & $5.2 \mathrm{aA}$ & $6.2 \mathrm{aA}$ & $5.3 \mathrm{abA}$ & $5.6 \mathrm{aA}$ & $0.0 \mathrm{aB}$ & $3.63 \mathrm{a}$ \\
43 & $5.2 \mathrm{aA}$ & $5.8 \mathrm{aA}$ & $6.1 \mathrm{aA}$ & $1.1 \mathrm{bB}$ & $0.0 \mathrm{aB}$ & $2.36 \mathrm{~b}$ \\
45 & $5.2 \mathrm{aA}$ & $3.6 \mathrm{bA}$ & $3.1 \mathrm{bA}$ & $0.0 \mathrm{bB}$ & $0.0 \mathrm{aB}$ & $0.0 \mathrm{C}$ \\
Mean & $5.20 \mathrm{~A}$ & $5.20 \mathrm{~A}$ & $4.80 \mathrm{~A}$ & $2.25 \mathrm{~B}$ & $\mathrm{CV}(\%)=0.12$ \\
\hline \multicolumn{5}{c}{$\mathrm{CV}=0$}
\end{tabular}

\begin{tabular}{lcccccc}
\hline \multirow{2}{*}{ Temperature $\left({ }^{\circ} \mathrm{C}\right)$} & \multicolumn{3}{c}{ Batch $2(2010)$} & Mean \\
\cline { 2 - 5 } & Initial (T0) & 24 & 48 & 72 & 96 & $4.84 \mathrm{a}$ \\
\hline 41 & $4.9 \mathrm{aA}$ & $4.8 \mathrm{aA}$ & $4.0 \mathrm{aA}$ & $5.3 \mathrm{aA}$ & $5.3 \mathrm{aA}$ & $4.17 \mathrm{a}$ \\
43 & $4.9 \mathrm{aA}$ & $4.0 \mathrm{aAB}$ & $4.5 \mathrm{aAB}$ & $5.0 \mathrm{aA}$ & $2.5 \mathrm{bB}$ & $3.37 \mathrm{~b}$ \\
45 & $4.9 \mathrm{aA}$ & $4.2 \mathrm{aA}$ & $4.8 \mathrm{aA}$ & $3.0 \mathrm{bA}$ & $0.0 \mathrm{cB}$ & $2.60 \mathrm{~B}$ \\
Mean & $4.90 \mathrm{~A}$ & $4.30 \mathrm{~A}$ & $4.41 \mathrm{~A}$ & $4.43 \mathrm{~A}$ & & \\
\hline
\end{tabular}

$\mathrm{CV}(\%)=0.09$

Means followed by different letters, lowercase in the column and uppercase in the line, are significantly different by Tukey test (5\% probability). CV (\%): coefficient of variation.

The use of vigor test for the assessment of physiologic quality of seeds has been recommended in the most different situations, notably for seeds of agricultural species (Santos and Paula, 2009). Bonner (1998) emphasizes that the accelerated aging and electric conductivity tests are promising, but also require extensive emergency tests in greenhouse to validate the results of laboratory tests. Torres et al. (1998) and Marcos Filho (2005) highlights that one single test will hardly be effective to satisfactorily assess the physiologic quality of different batches of seeds, however, several tests must be used for such purpose and for increased safety of information.

\section{Conclusions}

The water contents of the seeds, the fresh and dry mass of seedlings, are not effective to differentiate the physiologic quality of Crambe abyssinica seeds, harvested in different periods.

The accelerated aging test was found effective to assess the vigor of crambe seeds, and may be a promising alternative to assess the physiologic quality of seeds which present similar germination percentages.

The conduction of accelerated aging through the traditional method ( $100 \%$ UR) at 41 or $43{ }^{\circ} \mathrm{C}$ for 72 hours will enable the identification of batches with different vigor levels.

\section{Acknowledgements}

The authors acknowledge the MS foundation for donation of plant material, to CAPES and CNPq by awarding grants to first and second authors, respectively.

\section{Literature Cited}

Amaral, L.I.V.; Pereira, M.F.A.; Cortelazzo, A.L.

1995. Quebra de dormência em sementes de Bixa orellana. Revista Brasileira de Fisiologia Vegetal, v. 7, pp. 151-157. Artus, N.N.

2006. Arsenic and cadmium phytoextraction potential of crambe compared with Indian mustard. Journal of Plant Nutrition, v. 29, pp. 667-679.
Bedi, S.; Kaur, R.; Sital, J.S.; Kaur, J.

2006. Artificial ageing of Brassica seeds of different maturity levels. Seed Science and Technology, Zurich, v. 34, n. 2, pp. 287-296.

Bewley, J.D.; Black, M.

1994. Seeds: physiology of development and germination. 2. ed. New York: Plenum Press. 445 p. 
Bonner, F.T.

1998. Testing tree seeds for vigor: a review. Seed Technology, Lawrence, v. 20, n. 1, pp. 5-17.

Carvalho, N.M. De; Nakagawa, J.

2000. Sementes: Ciência, Tecnologia e Produção. Jaboticabal: FUNEP. 588p.

Delouche, J.C.; Potts, H.C.

1974. Programa de sementes: planejamento e implementação. 2. ed. Brasília-DF, AGIPLAN. 124 p.

Freitas, R.A.; Nascimento, W.N.

2006. Teste de envelhecimento acelerado em sementes de lentilha. Revista Brasileira de Sementes, v. 28, n. 3, pp. 59-63.

Jasper, S.P.; Biaggioni, M.A.M.; Silva, P.R.A.

2010. Comparação do custo de produção do crambe (Crambe abyssinica Hochst) com outras culturas oleaginosas em sistema de plantio direto. Revista Energia na Agricultura, Botucatu, vol. 25, n. 4, pp. 141-153.

Lopes, J.C.; Lima, R.V; Macedo, C.M.P.

2008. Germinação e vigor de sementes de urucu. Horticultura Brasileira, v. 26, pp. 19-25.

Maguire, J.D.

1962. Speed of germination aid in selection and evaluation for seeding emergence and vigor. Crop Sciense, Madison, v. 2, pp. 176-177.

Maia, A.R.; Lopes, J.C.; Teixeira, C. De O.

2007. Efeito do envelhecimento acelerado na avaliação da qualidade fisiológica de sementes de trigo. Ciência Agrotecnica, Lavras, v. 31, n. 3, pp. 678-684.

Marcos Filho, J.

2005. Fisiologia de sementes de plantas cultivadas. Piracicaba: FEALQ, p. 477.

Marcos Filho, J.

1999. Teste de envelhecimento acelerado. In: Krzyzanowski, F. C.; Vieira, R. D.; França Neto, J. B (Ed.). Vigor de sementes: conceitos e testes. Londrina: ABRATES, pp. 1-24.

Martins, L.D.; Costa, F.P.; Lopes, J.C.

2011. Light influence on seed germination of crambe (Crambe abyssinica Hochst.). Nucleus, v. 8, n. 1, pp. 405-412.

Masetto, T.E.; Quadros, J.B.; Moreira, F.H.; Ribeiro, D.M.; Benites Junior, I.; Rezende, R.K.S.

2009. Qualidade fisiológica e sanitária de sementes de crambe produzidas no estado de mato grosso do sul. Revista brasileira de oleaginosas e fibrosas, Campina Grande, v. 13, n. 3, pp. 107-113.

Paulose, B.; Kandasamy, S.; Dhankher, O.P.

2010. Expression profiling of Crambe abyssinica under arsenate stress identifies genes and gene networks involved in arsenic metabolism and detoxification. BMC Plant Biology, v. 10, n. 108 , pp. $1-12$.

Pitol, C.

2008. Cultura do crambe. Tecnologia e produção: milho safrinha e culturas de inverno 2008. Fundação MS.

Rossetto, C.A.V.; Novembre, A.D. Da L.C.; Marcos Filho, J.; Silva, W.R. Da; Nakagawa, J.

1997. Efeito da disponibilidade hídrica do substrato, da qualidade fisiológica e do teor de água inicial das sementes de soja no processo de germinação. Scientia Agrícola, Piracicaba, v. 54, n. 1/2, pp. 97-105.

Santos, S.R.G. Dos; Paula, R.C. De.

2007. Teste de envelhecimento acelerado para avaliação do vigor de lotes de sementes de Sebastiania commersoniana (Baill.) Smith \& Downs (Branquilho) - Euphorbiaceae. Revista do Instituto Florestal, São Paulo, v. 19, n. 1, pp. 1-12.

Santos, S.R.G. Dos; Paula, R.C. De.

2009. Testes de vigor para avaliação da qualidade fisiológica de sementes de Sebastiania commersoniana (Baill.) Smith \& Downs. Scientia Forestalis, Piracicaba, v. 37, n. 81, pp. 7-16.

Toledo, F.F.; Marcos Filho, J.

1977. Manual de sementes: Tecnologia e Produção. São Paulo: Ed. Agronômica Ceres. p. 224.

Torres, S.B.; Caseiro, R.F.; Rodo, A.B.; Marcos Filho, J. 1998. Testes de vigor em sementes de maxixe (Cucumis anguria L.) com ênfase ao teste de condutividade elétrica. Revista Brasileira de Sementes, Brasília, v. 20, n. 2, pp. 480-483.

Torres, S.B.; Marcos Filho, J.

2001. Teste de envelhecimento acelerado em sementes de maxixe (Cucumis anguria L.). Revista Brasileira de Sementes, Londrina, v. 23, n. 2, pp. 108-112.

Vázquez, E.; Montiel, F.; Vázquez-Ramos, J.M.

1991. DNA ligase activity in deteriorated maize axes during germination: a model relating defects in DNA metabolism in seeds to loss of germinability. Seed Science Research, Wallingford, v. 1, n. 2, pp. 269-273. 
